\section{Sustaining Existing and Prospective Passengers of Urban Public Buses: The Case Study of Rapid Kuantan, Pahang, Malaysia}

\author{
Zakiah Ponrahono $^{a^{*}}$, Syahriah Bachok ${ }^{\mathrm{b}}$, \\ Mariana Mohamed Osman ${ }^{\mathrm{b}}$, Mansor \\ Ibrahim $^{\text {b }}$
}

a Dept. of Environmental Management, Faculty of Environmental Studies, University Putra Malaysia, 43400 UPM Serdang, Selangor Darul Ehsan, Malaysia.

$b$ Kulliyah of Architecture and Environmental Design, International Islamic University Malaysia, Gombak, Malaysia Received: April 14, 2015/Accepted: March 16, 2016

\section{Abstract}

The paper introduces the various improvements implemented on buses in an eastern coastal city in Malaysia. Public buses in Malaysia, in general, and Kuantan, in particular, have been facing many challenges, including dwindling number of passengers and high costs of fleet maintenance. The research focused on the passengers' perspective of the new provision of bus services from the aspects of frequency, affordability, safety and security as well as comfort and convenience, all being sustainable public transport indicators adopted by Malaysia. Satisfaction with the current patronage and future aspiration were also evaluated against several quality measures of these buses and the waiting facilities. In ensuring the provision was sustainable, the company operating the bus services has also introduced disabledfriendly ramps for universal accessibility and on-board static and variable message signage and graphical presentation of bus routes and bus stops. Responses have been mixed on these value-added services. The research found that some socio-demographic and trip characteristics indeed influenced the current satisfaction levels, perceived services sustainability and passengers' expectation of future services. Improvements, hence, have been recommended to the bus operators and discussion with the management of the company has been undertaken to ensure future sustainability of Rapid Kuantan bus services.

Keywords:transport planning; public transport; passenger's aspiration; user perception.
Abbreviations:

\begin{tabular}{|lll|}
\hline GTP & $:$ & Government Transformation Program \\
CCTV & $:$ & Closed-Circuit Television \\
GPS & $:$ & Global Positioning System \\
NKRA & $:$ & National Key Results Areas \\
NA & $:$ & Not Available \\
RTPIS & $:$ & Real Time Passenger Information System \\
SPAD & $:$ & Suruhanjaya Pengangkutan Awam Darat \\
\hline
\end{tabular}

\section{Introduction}

One pre-requisite to sustainability is the management of travel and trip makings. For sustainability to be realized, growth of cities and towns must be accompanied by a corresponding growth in accessibility and mobility. In the past decade, the Malaysian population grew almost 2 percent per annum [1] with expansions of a city or urban boundaries doubling this rate [2]. Similarly, vehicles registered have increased almost 6 percent annually (annual average of 1.3 million new registrations, with a total of 23.7 million registered vehicles per 29 million population in 2013) [3]. In light of these unsustainable trends and patterns of mobility, the Malaysian government through various economic transformation packages including the (i) Vision 2020, (ii) the Malaysia Five Year Plan, (iii) National Key Results Areas (NKRA) and (iv) Government Transformation Programs (GTPs) has propagated the reversing of the public transportation images and annual dwindling patronage [4], [5]. Various improvements have been implemented onto city and rural bus systems, including a program undertaken recently by the city of Kuantan, located in Pahang, an eastern coastal state of the Peninsula.

Based on the Malaysian Ministry of Transport statistics [6], there existed some 62,672 buses registered in Malaysia, with 4,594 operating in the state of Pahang until $31^{\text {st }}$ December 2013. Many transformation programmes were carried out to enhance the bus system in Kuantan. For instance, the Rapid Kuantan system, a set of new bus fleets traversing main landuse activity centres, penetrating a few central business districts. The objectives of new operating system were to recapture the lost patronage and attracting the prospective passengers in the city of Kuantan. After Rapid Kuantan's first two years of introduction, there lied an opportunity to assess the effectiveness of the system and this paper reports the major analysis of the assessment exercise. 


\subsection{Study Objectives}

i. To explore the new provision of Rapid Kuantan bus services, system and operation

ii. To ascertain the passengers' perspective of the new provision of bus services in Kuantan

iii. To determine bus passengers' level of satisfaction of the new bus service of Rapid Kuantan

\section{Literature Review}

\subsection{Bus services in Malaysia}

In Malaysia, there are five major bus systems, each with its own respective function and purpose. These are stage bus system (intra-city), minibus system, express bus system (interstate, intercity), school and factory workers' bus system and feeder bus system [7]. Bus services in Malaysia comprise various forms of fleets, management and operations, scheduling, routing, stops and terminal, boarding and alighting facilities, fare and ticketing and passenger information systems [8].

Supply of buses is normally through either two ownerships or operative types. Some of the bus systems are quasi-government owned at the federal or state or even municipality levels, while the remainders are private operators, either wholly or leased to another operating company. In Peninsular Malaysia, the legislations related to public buses, in particular, stages buses have bestowed powers of, planning, developing, licensing, regulating and monitoring, execution and upgrading of the supply systems upon Suruhanjaya Pengangkutan Awam Darat (SPAD) or Land Public Transport Commission [9]. It is perceived that under this manner of governance, stage buses systems would be more effective, efficient and accountable to the general population who partially subsidise these operations.

Contemporary research has propagated that there is a lack of case study research on bus operation and its services sustainability in Malaysia. There is also a limited amount of studies on quantified indicators measuring the sustainability levels. Similarly, South East Asian study of the relationships between bus services characteristics or features and passengers' satisfaction levels have been scantily found in the available literature [10], [11]. A case study of a Malaysia city, with a typical set of issues and problems is considered useful to illustrate the sustainability assessment. Several contemporary literature has propagated the use of the following variables to assess the services sustainability levels: the number of operators, the number of the bus fleet, the route coverage of various bus operations, the percentage of main landuse activity points covered by designated routes, the bus speed and schedules/route adherence, the passenger load factors as well as the services duration and time period of service provision [12]-[14]. However, detailed and focused studies such as proposed were almost non-existence and further evaluation of urban public buses have become difficult and sparse.

\subsection{Passenger Satisfaction}

An excellent public bus service is important to support economic growth, a growing population, and an expanding of urban or rural activities [15]. The current bus systems adopted by many towns and cities, especially those in Malaysia, are not fully equipped to address the needs of the settlement forms, and socio-demographic and trip characteristics of the good urbanization process [8], [16]. These systems have portrayed a bad image on the overall connectivity and mobility in the urban or rural areas of Malaysia [5]. Hence, it is a acute need devoir for the transport stakeholders in Malaysia to ensure the availability of resources in providing effective and efficient public transport system.

A public bus service should provide a good accessibility that leads to a reliable, safe, and convenient transportation system [17]. In reality, however, if the quality of services is poor and unreliable, the public bus services tend to contribute to the worsening of the transportation system. There are a number of issues relating to public bus services such as the limitation of facilities, inconvenience fleet, the use of low quality of public bus facilities and interchanges, dispatching low passenger trips and long waiting time [18]. Hence, in order to facilitate high quality delivery of existing bus services, some measures should be imposed to examine the current performance of bus system [19]-[21].

Passengers' satisfaction survey is a tool to measure the performance and quality of bus service that sequentially useful as a benchmark or indicator to enhance the efficiency and effectiveness of bus service delivery and operations [22], [23]. It also defined as a judgment from the passengers that relates to the pleasurable level of consumption [24].

In normal practice of passengers' satisfaction level survey, attributes such as waiting time, reliability, service information, comfort, travel time, convinience, safety, security, affordability and frequency of service are assessed [24], [25]. It is the key component in measuring the bus services from the view of passenger [26].

Based on the two problem statements, this paper poses two main research questions. First, what are the stage bus levels of services in Kuantan from both the perspective of operators and users?. Second, how best can the existing Kuantan bus systems be improved in the short and medium terms so as to increase patronage for achieving the national transport sustainability target of 60:40 modal split favouring public transportation by the year 2020?.

\section{Research Methodology}

Two methods: survey and interview, were utilised for this research. The study employed survey questionnaire method for capturing the primary data related to passenger satisfaction levels and future intention of the repeat user. These two aspects have been adopted as sustainability 
indicators for Malaysian public transport sustainability levels. The unit of analysis for satisfaction survey was the bus rider, selected as a respondent when encountered by the enumerators. Convenience sampling technique was deemed most suited for this study due to the nature of moving vehicles within the specific distance, routes and speed driven by the drivers. Meanwhile, secondary data were sourced from interview sessions and published materials by the bus operators.

\subsection{On-board Transit Survey (Face to Face Intercept Survey)}

The survey was conducted from $8^{\text {th }}$ April 2014 to $13^{\text {th }}$ June 2014 for 13 routes of Rapid Kuantan bus services. On-board intercept face to face questionnaire survey has been utilised to capture the passengers demographic and travel characteristic. Face to face intercept survey ensured the comfort of passengers without compromising the limitation that was experienced by the enumerators to ask questions. Additionally, mobility and ease with which the enumerators move on board the buses and approach the prospective riders can also be maximised. Thus, sampling strategy may caused passengers seated or standing near, next to, behind, in front or beside the enumerators to have higher selection chances, when and if, a crash load of passengers' boarding reached maximum level or beyond the tolerable threshold.

\subsection{Respondents}

Using the convenience sampling technique, a minimum of 100 respondents with generic and homogeneous public bus users characteristic were selected to represent Rapid Kuantan bus passengers. Target respondent was on-board passengers in the range age of 13 to above 50 years old with common travel behaviour of routinely commuting using a public bus service ${ }^{13 .}$ An optimal 200 survey forms were distributed. However, after data cleaning, only 130 survey forms were analysed for generalisation purposes.

\subsection{Questionnaire}

Respondent's socio-demographics were asked to the respondents who were accessible and volunteered to provide feedbacks during the on-board survey. Systematic coding were applied and filled up by the enumerators appointed. The questionnaire is categorized into four (4) sections:

i. Section A consisted of questions regarding respondent's socio-demographics.

ii. Section B posed questions about the trips characteristic, and the level of satisfaction with current bus services based on selected sustainability indicators.

iii. Section $C$ focused on the willingness to pay more expensive bus ticket and aspiration.

iv. Section D captured the data on suggestions to improve the current bus service.

\subsection{Interview}

To obtain information on bus service details and a route network, the study also conducted a few interview sessions with the managers, operators and bus drivers.

\subsection{Case Study of Kuantan, Pahang}

Kuantan (Figures 1 and 2), is the capital city of Pahang, with a population of $600,000^{1}$ and a size of $324 \mathrm{~km}^{2}$. The city was selected as a case study because it:

- Represented an urban area in the eastern part of Peninsular Malaysia

- Has a public transport which was under the initiatives of Government Transformation Programmes (GTPs)

- Has recently being introduced to the Rapid Kuantan system with a set of new bus fleets and new operating system aimed at recapturing the lost patronage and attracting the prospective passengers.

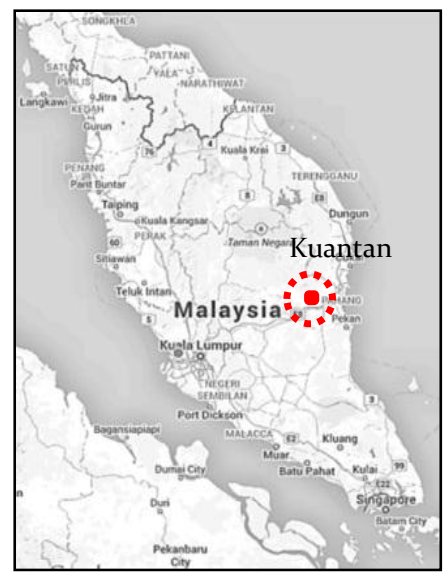

Figure 1 Location of Kuantan within the Peninsular Malaysia Context.

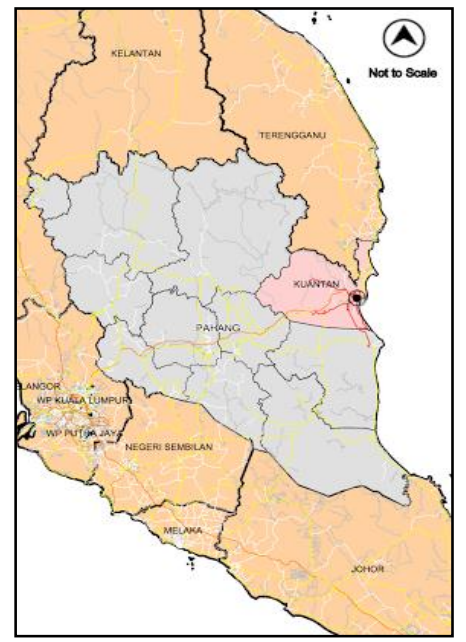

Figure 2 Site plan of Kuantan District within Pahang State, Peninsular Malaysia.

Figures 3 and 4, and Table 1 showed the services utilized by Kuantan's population. 
Table 1 Selected Bus Operators \& Respective Route coverage in Pahang, 2012.

\begin{tabular}{|c|c|c|c|}
\hline Operator & No & Route & $\begin{array}{l}\text { Operating } \\
\text { Status }\end{array}$ \\
\hline \multirow[t]{13}{*}{$\begin{array}{l}\text { Rapid } \\
\text { Kuantan }\end{array}$} & 100 & $\begin{array}{l}\text { Hentian Bandar to } \\
\text { Gambang Resort }\end{array}$ & Active \\
\hline & 101 & $\begin{array}{l}\text { Hentian Bandar to Indera } \\
\text { Sempurna }\end{array}$ & Active \\
\hline & 102 & $\begin{array}{l}\text { Hentian Bandar to } \\
\text { Permatang Badak }\end{array}$ & Active \\
\hline & 200 & $\begin{array}{l}\text { Hentian Bandar to Teluk } \\
\text { Chempedak }\end{array}$ & Active \\
\hline & 201 & $\begin{array}{l}\text { Hentian Bandar to Taman } \\
\text { Gelora }\end{array}$ & Active \\
\hline & 300 & $\begin{array}{l}\text { Hentian Bandar to Taman } \\
\text { Impian }\end{array}$ & Active \\
\hline & 301 & $\begin{array}{l}\text { Hentian Bandar to Bukit } \\
\text { Sagu }\end{array}$ & Active \\
\hline & 302 & $\begin{array}{l}\text { Hentian Bandar to Indera } \\
\text { Mahkota }\end{array}$ & Active \\
\hline & 303 & $\begin{array}{l}\text { Hentian Bandar to } \\
\text { Terminal Sentral Kuantan }\end{array}$ & Active \\
\hline & 400 & Hentian Bandar to Pekan & Active \\
\hline & 401 & $\begin{array}{l}\text { Hentian Bandar to } \\
\text { Kampung Ubai }\end{array}$ & Active \\
\hline & 500 & $\begin{array}{l}\text { Hentian Bandar to Sungai } \\
\text { Lembing }\end{array}$ & Active \\
\hline & 601 & $\begin{array}{l}\text { Hentian Bandar to } \\
\text { POLISAS }\end{array}$ & Active \\
\hline
\end{tabular}

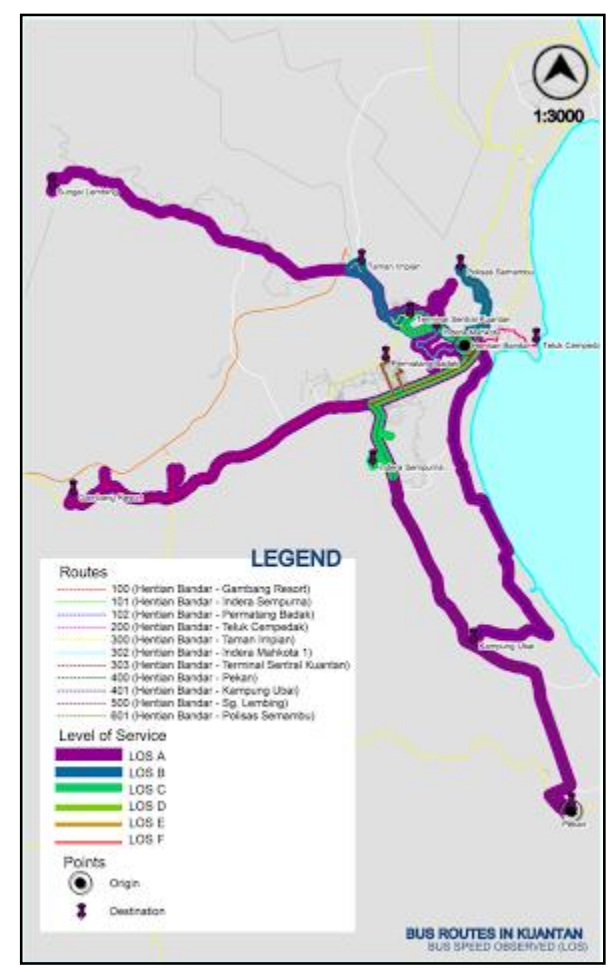

Figure 3 The catchment area of public bus routes in Kuantan

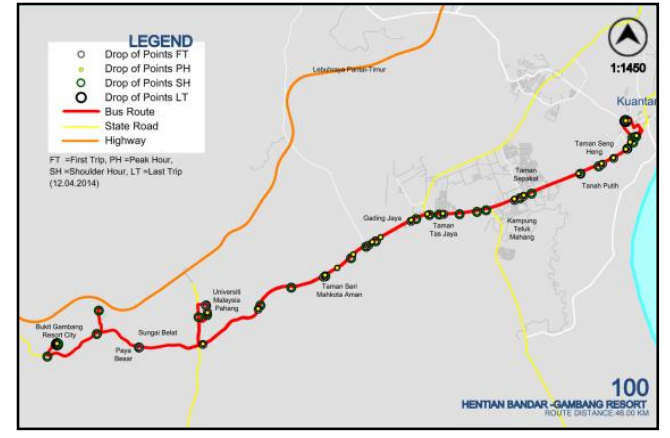

Figure 4 An example of Rapid Kuantan's Service Route map

\section{Data Analyses and Discussions}

\subsection{Passengers' satisfaction and future intents}

Beginning its services on December 2012, Rapid Kuantan has been operated by the Prasarana Group (a government linked public company, specializing in consolidating major city bus services). The first 3 routes of bus services (refer oTable 2) are:

Table 2 Early Stage of Rapid Kuantan Bus Routes Services

\begin{tabular}{|c|c|c|c|}
\hline No. & Routes & Details ser & \\
\hline \multirow[t]{10}{*}{1.} & Gambang & Frequency & Every 15 minutes \\
\hline & (Kolej & No. of fleet & 14 \\
\hline & Komuniti) & Travel & 95 minutes \\
\hline & $\begin{array}{l}\text { to Terminal } \\
\text { Makmur }\end{array}$ & $\begin{array}{l}\text { time } \\
\text { Distance }\end{array}$ & $49.4 \mathrm{~km}$ \\
\hline & & Catchment & Universiti \\
\hline & & & Pahang (UMP), Airport \\
\hline & & & Kuantan, Taman TAS, \\
\hline & & & Sg. Isap, Hospital \\
\hline & & & $\begin{array}{lcr}\text { Tengku Ampuan } & \text { Afzan } \\
\text { (HTTA) and } & \text { State }\end{array}$ \\
\hline & & & Mosque. \\
\hline \multirow[t]{10}{*}{2.} & Bandar & Frequency & Every 15 minutes \\
\hline & Indera & No. of fleet & 7 \\
\hline & $\begin{array}{l}\text { Mahkota ke } \\
\text { Teluk }\end{array}$ & $\begin{array}{l}\text { Travel } \\
\text { time }\end{array}$ & 46 minutes \\
\hline & Cempedak & Distance & $18.4 \mathrm{~km}$ \\
\hline & & Catchment & Penyayang, \\
\hline & & & Taman Cenderawasih, \\
\hline & & & Mahkota \\
\hline & & & 2,Terminal \\
\hline & & & Kolej IKIP/MRSM \& \\
\hline & & & Teluk Cempedak. \\
\hline \multirow[t]{6}{*}{3.} & Kompleks & Frequency & Every 15 minutes \\
\hline & Mahkamah & No. of fleet & 8 \\
\hline & to POLISAS & Travel & 52 minutes \\
\hline & Semambu & time & \\
\hline & & Distance & $21 \mathrm{~km}$ \\
\hline & & Catchment & NA \\
\hline
\end{tabular}

At the early stage of its operation, Rapid Kuantan deployed 32 buses that were installed with the air conditioning system, GPS and being ergonomic to disabled passenger (with provision of space for standard wheelchair, a boarding 
device to enable wheelchair users to get on and off, priority seats, handrails, color contrast and easy bell pushes). Details on the operation plan, management and staff recruitment are described in the Table 3.

Table 3 Data on Operating System of Rapid Kuantan ${ }^{14}$

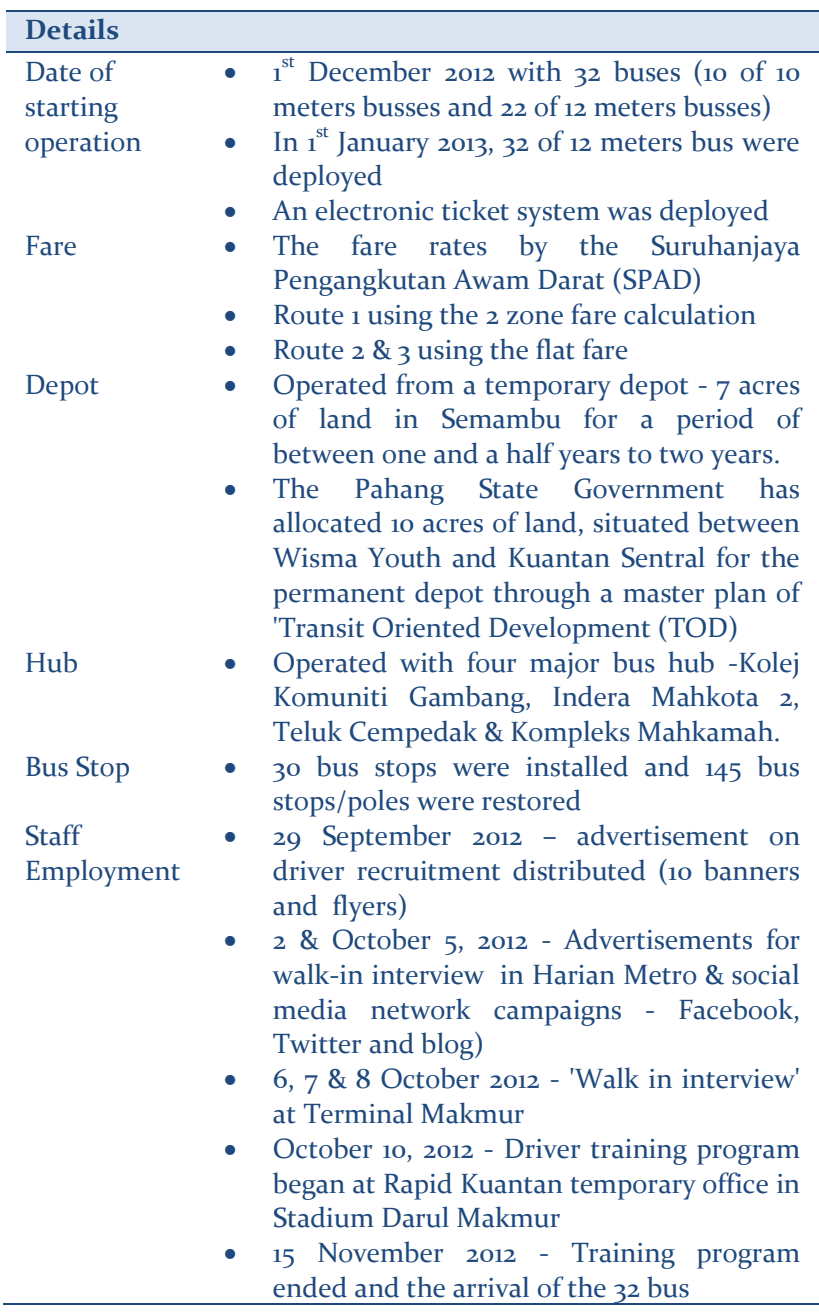

Passengers' satisfaction and future intention of repeat use were two important measures, indicating sustainability of a bus services. In general, passengers' satisfaction was a judgment on level of service made on the basis of a specific service encountered. In the case of Rapid Kuantan bus services, it was important to assess the passengers' satisfaction and aspiration after the full services and more routes had been in place. It was based on these two measurements that this study assessed the bus operation capacity to sustain existing and prospective passengers of Kuantan's public buses.

\subsection{Passenger Survey Analysis}

From the survey of 130 forms completed, both descriptive and inferential analyses have been carried out. Some $48.5 \%$ of passengers surveyed were females, indicating that buses attracted mainly female passengers because female were captive riders, most not owning a vehicle or having an access to alternative modes of transport (Table 4). The age group of the respondents was classified into four categories; schooling age (40.8\%), college student and young working group (48.5\%), mature working group (8.5\%) and elderly (2.3\%). More than $80 \%$ of the respondents were from the age group of $13-28$ old, indicating the captive riders may be in the form of school children, college and university student and young working group who did not have immediate access to private car or must use public transportation to travel (Table 4).

Table 4 Rapid Kuantan Ridership Profile Distribution

\begin{tabular}{lcc}
\hline Variables & Frequency & Percentage (\%) \\
\hline Gender & 54 & 41.5 \\
\hline Male & 76 & 58.5 \\
Female & & \\
\hline Age Group & 53 & 40.8 \\
\hline 13-18 years old (schooling age) & 63 & 48.5 \\
19-28 years old (college student & & \\
and young working group) & 11 & 8.5 \\
29-49 years old (mature working & & \\
group) & 3 & 2.3 \\
Above 50 years old (elderly) & & \\
\hline Ethnic & 98 & 75.4 \\
\hline Malay & 15 & 11.5 \\
Chinese & 15 & 2 \\
Indian & 2 & 3.5 \\
Others & & \\
\hline Purpose of bus ridership & 5 & 43.8 \\
\hline Travel to the education center, & & 6.2 \\
area (school, college \& & & 5.8 \\
university) & 57 & \\
Working & 7 & \\
Saving & 53 & \\
Shopping and leisure activities & 7 & \\
Mode for long distance travel & & \\
\hline
\end{tabular}

Initially, crosstabulation analysis did not show much satisfaction difference between different age group, ethnic and gender upon bus service, frequency, effectiveness and efficiency, punctuality, aspiration on fare rate and willingness to pay. However, tests of correlation further inspected that there existed a significant difference among various ethnics when expressing aspiration towards punctuality of bus services $(\mathrm{p}=0.009)$ and within age groups in willingness to pay and bus frequency $(\mathrm{p}=.034, \mathrm{p}=$ o.o11 respectively).

Table 5 Summary Of Chi-Square Analyses

\begin{tabular}{lccc}
\hline Variables & \multicolumn{3}{c}{ Chi-Square (P Value) } \\
& Age & Ethnic & Gender \\
\hline Satisfaction on overall bus service & .521 & .972 & .646 \\
Frequency & $.011^{*}$ & .100 & .328 \\
Effectiveness and Efficiency & .052 & .698 & .126 \\
Punctuality & .070 & $.009^{*}$ & .119 \\
Aspiration on Fare Rate & .866 & .995 & .347 \\
Willingness to Pay & $.034^{*}$ & .597 & .553 \\
\hline
\end{tabular}

Note: Level of significance is at $\mathrm{p} \leq .05$ 
Table 6 shows the correlation of willingness to pay, aspiration on fare rate, and age.

Table 6 Correlation Analysis on Willingness to Pay, Aspiration on Fare Rate, and Age

\begin{tabular}{lccr} 
& $\begin{array}{c}\text { Willingness } \\
\text { to Pay }\end{array}$ & $\begin{array}{l}\text { Aspiration on } \\
\text { Fare Rate }\end{array}$ & $\begin{array}{r}\text { Ag } \\
\text { e }\end{array}$ \\
\hline Aspiration on Fare Rate & $.020^{*}$ & -- & \\
Age & $.026^{*}$ & .916 & -- \\
\hline
\end{tabular}

${ }^{*}$ Level of significance is at $\mathrm{p} \leq .05$.

Further, in Table 6, it can be seen that willingness to pay correlated with aspiration on more affordable fare rates and age group $(\mathrm{p}=0.020$ and $\mathrm{p}=0.026$ respectively). This implied that that willingness to pay for more expensive fare rate was highly correlated with the aspiration and age group of respondents.

Higher (73.2\%) level of passengers' satisfaction and perception (Table 7) on the current Rapid Kuantan bus service can be also be generalized. In other words, indicators expressed have received positively as direction towards public transport sustainability by Kuantan's population who had experienced upgrading and improvement of bus services since the previous couple of years. Whilst Kuantan is a unique case study for the global generalisation, it has every feature of developing cities' buses characteristics, making it possible for this research to extend its assessment to other bus services in the ASEAN region, using the same methodologies.

Table 7 Satisfaction with Current Bus Service

\begin{tabular}{lcc}
\hline Bus Services Level & Frequency & Percentage (\%) \\
\hline Good & 120 & 92.3 \\
Average & 8 & 6.2 \\
Not Good & 2 & 1.5 \\
\hline
\end{tabular}

In sustaining the existing passengers, various suggestions have been forwarded by the passengers surveyed (Table 8). The highest ranked was the maintenance of bus condition $(46.92 \%)$. This result has high validity and reliability because respondents were travelling on the bus service for more than ihours journeys and indeed, the condition of bus influenced the level of sustainability, i.e. latent variables of comfort and satisfaction.

Table 8 Suggestion of Improvement on Current Bus Service

\begin{tabular}{lcc}
\hline Improvement & Frequency & Percentage (\%) \\
\hline $\begin{array}{l}\text { Maintenance of } \\
\text { bus condition }\end{array}$ & 61 & 46.92 \\
Adding more & 25 & 19.23 \\
seating & & \\
Frequency of bus & 22 & 16.92 \\
Driver attitude & 8 & 6.15 \\
Information and & 4 & 3.08 \\
Electronic Card & & \\
System & & \\
Punctuality & 4 & 3.08 \\
Wifi installation & 4 & 3.08 \\
Safety & 2 & 1.54 \\
\hline
\end{tabular}

The second highest ranked was adding more seating $(19.23 \%)$. The respondents perceived that more seating should be provided as the number of passengers during peak hours was high. The third was the frequency of the bus (16.92\%). This improvement was important because, in general, the greater increase in passenger numbers would be followed by an increase in the service frequency. Riders also responded that for buses to capture more passengers, the following improvements have to be made within the next couple of years:

i. Improvements in driver attitude towards passengers $(6.15 \%)$

ii. Improvements in information system and electronic card system (3.08\%)

iii. Punctuality (3.08\%)

iv. Wifi installation in bus vehicle (3.08\%)

v. Safety aspect (1.54\%)

In addition, the research has also conducted convenience sampling test of aspiration of non-users. At terminal and bus stops, some passers by and prospective users have also been probed to provide scenarios which would attract them to use the buses in the future as an alternative to the current transport mode they were using. They preferred that buses would be modern and futuristic in exterior with Real Time Passenger Information System (RTPIS) provision. The responses indicated that current Rapid Kuantan have to improve its bus services in order to capture more ridership and to sustain its services in the longer term. It also indicated the public bus service demand in Kuantan was realisitically high.

Bus operators, managers and drivers were in the opine that the followings were essential to sustain existing and capture prospective passengers of Rapid Kuantan. First was to provide air conditioning system within the vehicles, clean interior and better Real Time Passenger Information System (RTPIS). Indeed, some $46.92 \%$ of respondents aspired for a better maintenance of bus condition for. Second was to install the electronic card fare payment system in the bus vehicles. The suggestion was purposely designed to increase and improve the travel time, headways and passenger satisfaction during boarding time.

Finally, the recent technology applied in the bus vehicle included latest GPS, CCTV, Real Time Passenger Information System (RTPIS) and more ergonomic design for all types of users will increase the efficiency and effectiveness of the bus service. These have been the main attraction of the new bus system in Kuantan. This bus new attraction and image building will improve the public transport system of the city and capture more numbers of ridership in the future.

\section{Conclusion}

This research on measures of sustaining existing and capturing prospective passengers of urban buses in Kuantan has achieved the set objectives of exploring the bus services 
system and operation, ascertaining the passengers' perspective and determining the level of satisfaction with the new bus services provided by Rapid Kuantan.

From the analysis of both the survey and interviews, it was found that the early Rapid Kuantan bus service was comparatively good, when compared to those of developing cities. Indicators of sustainable public transport in developing cities such as Kuantan may differ from the rest of global megacities. However, many improvement aspects may increase the level of service and capture more prospective passengers such as the more frequent maintenance of bus condition, increased bus frequency, seating provision and better driver attitude. Based on the findings too, it can be generalized that captive riders included female passengers, schooling and young working groups who did not have immediate access to private car or must use public transportation to travel, may turn out to be saviours of dying public transportation services.

For buses to maintain its current passenger loads or even increase the patronage, it is essential that the proposed improvements be implemented in the coming two years. Kuantan bus systems are typical to many other developing cities' urban bus systems. Hence, this suggested initiative and improvement programmes for buses can be transferred and applied to cities such as Ipoh, Georgetown and Klang Valley or even ASEAN cities.

It is the goal of the Malaysian government transformation programmes to achieve a 60:40 modal split favouring public transportation by the year 2020. It is, hence, recommended that the outlined programmes for buses improvement be promoted in a timely manner for such target to be achieved in 6 years to come. This research has therefore presented the overarching findings and farreaching way forwards for urban buses in Malaysia, in general and Kuantan specifically. Lessons to be learned from this study can be concluded as the demand on public bus service is high, yet the current service has many aspects to improve in achieving the high level of service and sustainable system.

\section{References}

[1] Department of Statistic Malaysia, "Intercensal Mid-Year Population Estimates," 2014.

[2] Federal Department of Town and Country Planning Ministry of Housing and Local Government of Malaysia, "Second National Physical Plan (NPP-2)," 2010.

[3] Ministry of Transport Malaysia, "Total Motor Vehicles by Type and State, Malaysia, Until 31st December 2013," 2014. [Online]. Available: http://www.mot.gov.my/my/Statistics/Land/2013 4 SUKU IV 2013/Jadual 1.2.pdf.

[4] R. Kamaruddin, I. Osman, C. Anizaliana, and C. Pei, "Customer Expectations and its Relationship Towards Public Transport in Klang Valley," J. ASIAN Behav. Stud., vol. 2, no. 5, pp. 29-38, 2012.

[5] A. A. Aziz and N. F. M. Amin, "Transforming the Land Public Transport System in Malaysia," JOURNEYS, no. May, pp. 30-37, 2012.
[6] Ministry of Transport Malaysia, "Ministry of Transportation," 2014 .

[7] A. R. M. Nor and N. G. M. Nor, "Empowering Public Transport for Urban Environmental Management," Malaysian J. Environ. Manag., vol. 7, pp. 93-111, 2006.

[8] K. Jayaraman, J. Choong, S. Suan, and S. K. Lin, "Robust models for the utilization of public bus transport services in Malaysia," African J. Bus. Manag., vol. 5, no. 26, pp. 10586-106oo, Oct. 2011.

[9] Land Public Transport Commission (SPAD), "National Land Public Transport Masterplan," 2012.

[10] M. Yajima, K. Sakamoto, and H. Kubota, "Efficacy of bus service reorganization utilizing a hub-and-spoke topology and DRT to meet community needs: A case study of tokigawa town," IATSS Res., vol. 37, no. 1, pp. 49-6o, 2013.

[11] X. Chen, L. Yu, Y. Zhang, and J. Guo, "Analyzing urban bus service reliability at the stop, route, and network levels," Transp. Res. Part A Policy Pract., vol. 43, no. 8, pp. 722-734, 2009.

[12] L. Dell'Olio, A. Ibeas, and P. Cecin, "The quality of service desired by public transport users," Transp. Policy, vol. 18, no. 1, pp. 217-227, 2011.

[13] Â. Ibeas, L. dell'Olio, B. Alonso, and O. Sainz, "Optimizing bus stop spacing in urban areas,” Transp. Res. Part E Logist. Transp. Rev., vol. 46, no. 3, pp. 446-458, 2010.

[14] T. T. Anh, B. Q. Hung, and Y. Tanaboriboon, "Analyzing Of Bus Service In Hanoi , Vietnam,” in Proceedings of Eastern Asia Society for Transportation Studies, 2005, vol. 5, pp. 352-362.

[15] S. Bachok, M. M. Osman, and Z. Ponrahono, "Passenger's Aspiration Towards Sustainable Public Transportation System: Kerian District, Perak, Malaysia," Procedia - Soc. Behav. Sci., vol. 153, pp. 553-565, Oct. 2014.

[16] H. M. Noor, N. Nasrudin, and J. Foo, "Determinants of Customer Satisfaction of Service Quality: City Bus Service in Kota Kinabalu, Malaysia,” Procedia - Soc. Behav. Sci., vol. 153, pp. 595-605, Oct. 2014.

[17] A. Amiril, A. H. Nawawi, R. Takim, and S. N. F. A. Latif, "Transportation Infrastructure Project Sustainability Factors and Performance," Procedia - Soc. Behav. Sci., vol. 153, pp. 9098, Oct. 2014.

[18] M. M. Rohani, D. C. Wijeyesekera, and A. T. A. Karim, "Bus operation, quality service and the role of bus provider and driver," Procedia Eng., vol. 53, pp. 167-178, 2013.

[19] Suwardo, M. Napiah, and I. B. Kamaruddin, "Review on Motorization and Use of Public Transport in Perak Malaysia: Realities and Challenges," in 2nd International Conference on Built Environment in Developing Countries (ICBEDC20o8), 2008.

[20] Suwardo, M. B. Napiah, and I. B. Kamaruddin, "Puncuality and Expected Waiting Time of Stage Buses in Mixed Traffic," J. Transpotasi, vol. 8, no. Edisi Khusus No. 3, pp. 213-226, 2008.

[21] M. Napiah, amirah suriati A. Farid, and Suwardo, "Trip Productibity Evaluation of Bus Service: Medan Kidd Bus Station," in Proceeding of Malaysia Universities Transportation Research Forum and Conferences 2010 (MUTRFC2010), 2010, vol. 2010, no. December, pp. 1-10.

[22] Suwardo, M. B. Napiah, and I. B. Kamaruddin, "On-Time Performance and Service Regularity of Stage Buses in Mixed Traffic," Int. J. Civil, Archit. Sci. Eng., vol. 3, no. 7, pp. 1-8, 2009.

[23] N. H. Castillo, "A Methadological Approach For Indicator-Based Sustainable Transport Assessment," Loughborough University, 2004. 
[24] R. Ismail, M. H. Hafezi, R. M. Nor, and K. Ambak, "Passengers Preference and Satisfaction of Public Transport in Malaysia,” Aust. J. Basic Appl. Sci., vol. 6, no. 8, pp. 410-416, 2012.

[25] Y. J. Nakanishi, "Bus Performance Indicators On-Time Performance and Service Regularity,” Transp. Res. Rec., vol. 1571, no. August, pp. 3-13, 1997.

[26] Transportation Research Board, "Part 2 Bus Transit Capacity," in Transit Capacity and Quality of Service Manual Third Edition, 2013, pp. 2-1 to 2-96. 